Global Conferences Series:

Social Sciences, Education and Humanities (GCSSSEH), Volume 2, 2019

The $2^{\text {nd }}$ International Conference on Sustainable Development \& Multi-Ethnic Society

DOI: https://doi.org/10.32698/GCS.0175

\title{
The Use of I -Think Maps to Increase Mastery of Facts in History Education
}

\author{
Esther Daya Setar ${ }^{1}$, Mohd Mahzan Awang ${ }^{2}$ \& Shakila Che Dahalan ${ }^{3}$ \\ ${ }^{1}$ SMK Lawas, MALAYSIA \\ ${ }^{23}$ Faculty of Education UKM, MALAYSIA \\ E-mail: ezzmike8889@gmail.com
}

\begin{abstract}
Today, we often hear approaches used by history teachers over traditional versions of chalk and talk. The use of I-Think thinking maps in teaching and learning in the classroom will provide students with a new experience in learning history. Accordingly, the government through the Malaysian Innovation Agency (AIM) in collaboration with the Ministry of Education Malaysia (KPM) has introduced the i-THINK Program. In schools throughout Malaysia with the aim of enhancing and cultivating thinking and teaching skills in order to produce creative-minded students. Teachers have been exposed to the I-THINK program through courses organized by the MOE and the school. The discussion of this research paper focuses on definitions, theories, literature, problems. In turn, this paper also discusses the suggestion that the use of I-Think maps can enhance student interest in history. The explanations in this concept paper is intended to expose many parties to the importance of applying I-Think thinking maps to create a meaningful and enjoyable 21 st-century teaching and learning process.
\end{abstract}

Keywords: I-Think, 21st century learning, skills

\section{Introduction}

History subjects have been introduced into our country's education system since the time of the British occupation by teaching history subjects in English-language schools and Malay-language schools. After the second world war, emphasis was placed on history subjects to enhance the value of racial unity in Malaysia. In 1989, the Ministry of Education Malaysia made history subjects a core subject for which all students were required to take the course. In 2012, the government made a wise move by making history subjects required to pass the Malaysian Certificate of
Education (SPM) examination. The Mind Map introduced through the i-THINK program is a thinking tool developed by Dr. David Hyerle presented in eight easy-to-understand and easy-to-use visual Map of Mind maps. Each Mind Map has its own thinking process and it can be customized using the title (KPM, 2012).

I-THINK means Innovative Thinking. Students need to be provided with thinking skills to prepare them for problem solving. Each Thinking Map has its own thinking process and it can be customized by title (KPM, 2012). ITHINK mind map program developed by the ministry to enhance and cultivate thinking skills among students towards 
producing creative, critical and innovative students. The ITHINK thinking map is used based on the thought process to be used in a title, for example to make a comparison between $\mathrm{A}$ and $\mathrm{B}$ requires a different reasoning process. The most suitable map is the Double Bubble Map.

To produce people who are self-reliant, loyal to the nation and nation and without neglecting the soft skills of teaching and learning history is the prime goal of the ministry. Emphasis on the value of patriotism and empathy in the younger generation is also a major goal in the subject of history. According to Kamarul Afendey and Isaac (2013), emphasis is also placed on aspects of thinking skills, analyzing and evaluating historical facts rationally based on preservation skills in historical education.

\section{Problem statement}

The development of thinking skills is less emphasized in schools (Balakrishnan, 2002; Rajendran, 2001) and does not take place in a course or subject specifically related to learning thinking skills in high school (Tee, 2013). The teaching and learning process in the classroom requires that teachers use innovation and creativity to make the learning environment in the classroom both student-centered and student-centered. Teaching and learning methods in college make history history one of the most frustrating subjects. Teachers may find that the method is still relevant today and students will easily understand the facts with clear explanations. The use of I-Think thinking maps and concept maps will give students a new experience in learning history. If teachers really use the eight I-Think thinking maps well, then the teaching and teaching process will be more fun in the classroom.

I-Think's mind map was developed by Dr. David Hyerle features eight easy-to-use and easy-to-understand visual maps. Each of the eight I-Think Thinking maps has its own functionality and can be selected according to the teaching and learning title (KPM, 2012). According to Wineburg (2001), historical thinking skills do not exist among students, rather they need to be nurtured by collecting, reading and analyzing various historical evidence. Therefore, teachers need to present evidence such as artifacts, old documents and new discoveries as found in the national archives in the process of teaching and learning history. The use of mind maps is best used for the purpose of summarizing notes and facts so that students can better understand and remember events. The notes made by applying the use of the mind map can be easily illustrated and understood compared to the notes in full essay (Taha, 2004). In other words, thinking tools are instruments that can assist in making verbal management, visually and intellectually manageable (Noraida Endut and Noor Shakirah
Mat Tahir, 2008). Through the use of appropriate teaching and learning tools, students' mastery of thinking skills becomes more effective (Arfah, 2013).

\section{Theory}

The theory used in this research paper is that Lev Vygotsky's theory of constructivism has transformed the existing traditional teaching scenario in Malaysia, which is teachercentered and student-centered teaching. According to Yahya et al. (2009), this is because the theory describes the learning process as an active and sociocultural process. This is supported by Harkirat et al., (2010), who says that in general, the combination of mind map and modern theory of constructivism in learning is appropriate. This is because learning through the theory of constructivism emphasizes the active involvement of students that leverages existing knowledge structures and builds on the new knowledge gained by integrating the two in their memory. In addition, learning through the theory of constructivism encourages cooperative and collaborative learning that enhances student achievement in Science subjects (Yahya \& Othman, 2012)

Cognitive-based learning theories emphasize how individuals can retain information in their memory through long-term memory skills. According to Mat Jamudin (2002), if an individual is able to use long-term memory, he or she can build a network of connected and structured knowledge which if scanned or needed. According to this theory, in the first stage the student's focus will be on stimulus materials. Memory at this level is known as sensory memory. According to Lefrancois (2000) in Mat Jamudin (2002), attention is needed to determine whether students are focusing on what to discuss. The information received by this memory is in the form of objects and events happening around it. This memory capacity is not limited to the amount of information that can be stored but if processing does not occur immediately, the information is lost quickly (Leahey \& Harris 1997).

\section{Definition}

\section{1 l-Think Map}

The I-Think program was first introduced in 2011 by the Ministry of Education Malaysia. The purpose of the introduction of the program is to strengthen and cultivate thinking skills among students towards creating creative and critical thinking students. I-Think carries the meaning of Innovative THINKing. According to Balakrishnan (2014), the I-Think program emphasizes the teaching and learning approach by using mindfulness as a complement to the learning process. There are eight types of thinking tools 
used: Circle Map (Bubble Map), Bubble Map, Double Bubble Map, Tree Map, Brace Map, Flow Map), multi-Flow Map (Bridge Map), and Bridge Map (Bridge Map). All of these mind maps have features that can only be used for certain facts or information. For example, foam maps can only be used to describe things using adjectives only and subject maps are used to segment information into specific categories, for example, sub-topics and descriptions.

\subsection{Mind Map}

According to Bletsas, (2011), mind map is a useful tool for centralizing important ideas such as using visual maps. The use of visual maps will help students organize information in a structured way, understand, disseminate, recall and come up with new ideas. In other words, it is able to remember information through the mind map and help the human brain work faster. The use of mind maps is one of the processes of affective learning by applying ideas from one concept of knowledge to a related branch. The mind map is also a graphical arrangement that highlights important information, written concisely and concisely.

\section{Literature Review}

According to Hyerle and Yeager (2007), thinking maps make it easier for students to understand concepts, analyze problems and find solutions. Many studies have been conducted since the program was introduced. For researchers Sidek \& Ahmad (2012), the teaching and learning process that applies the i-THINK Program based on the latest technology is faster and more effective. In addition, Sidek's (2013) paper explores the role and importance of the iTHINK Program in transforming the mind as an access to new thinking skills. This paper explains the eight forms of Thinking Map created by Dr. David Hyerle is an innovative teaching and learning technique that involves innovation in thought and is very relevant in the 21 st century.

Zaharah \& Nurliah (2009) in their study The Use of Draft Map to Improve History Curriculum Performance for Secondary Students shows that students can better embrace the use of concept maps in the teaching and learning process. The study also stated that students also showed a positive attitude towards History subjects by showing interest in studying History subjects (Zaharah et al. 2009). Overall, the mean score for students' acceptance of concept maps in the teaching and learning process of History was 3.55 which was positively moderate (Zaharah et al. 2009).

The study conducted by Mahzan, Razak \& Muhaimi (2014), which is a subject of History, has many abstract ideas and concepts that are difficult to understand. This concept plays a very important role in shaping the thinking of an individual and shaping the intellectual capacity of students. By using the mind map method, all the historical notes filled with facts can be shortened using various symbols, colors, patterns and so on. This will make it easier for students to remember all the facts that have been diffused through the mind map. Subdistrict Study et. al (2005) also state that the use of Needham's Five Phase Constructivism Model in teaching and learning History is very effective and can help students understand the concept and master the content of the history lesson subject.

A study conducted by Yahya Othman and Azmey Othman (2012) found that the use of mind maps in argumentative essay teaching and learning in an Arab secondary school in Brunei Darussalam showed that the sample performance of the experimental group was higher and significantly higher than that of the control group. The findings of this study show that mind map is one of the R\&D alternatives that teachers can use in teaching essay lessons. The use of mind maps enables students to think critically and creatively. In addition, using mind maps, students will be actively engaged and create a fun learning environment.

According to Tony Buzan (2001), the mind map is the diffusion of ideas from a concept or title to form a network of branches of an idea. Mind maps encourage students to explore lessons when concepts are easy to apply and easy to understand. A student's cognitive function is also something that drives mental illness. The situation changes based on experience, human behavior and the surrounding environment. Cognition is very important in driving the psychomotor movement. When the cognitive is attracted to a mind map learning module, it activates the psychomotor and indirectly triggers the desire to repeat the learning independently.

According to Hyerle (2000), thinking maps can change teachers' perceptions and expectations. He found that thinking maps became a tool that bridged the cultural gap between teachers and students. Each thinking map can enhance students' cognitive skills, which include defining concepts, explaining, identifying, categorizing and organizing information, organizing, comparing differences, causes and consequences, analyzing and making decisions. Through a mind map, teachers and students can communicate effectively. Eventually, students will gain the confidence to communicate.

\section{Challenges and Suggestions}

The challenges faced in implementing the use of I-Think thinking maps relate to teachers' understanding of using eight types of I-Think maps effectively in pdpc activities. Teachers' understanding of the full use of the I-Think map is 
very helpful in making pdpc more interesting especially in history subjects. Students become more aware of the facts when pdpc activities use mind maps like I-Think maps. History subjects are not subjects that appeal to students in school especially in high school. Students think that history subjects are boring subjects. The reason is given following too many facts that students need to remember. This challenge provides a great slap to history teachers for being more creative in pdpc activations. The use of I-Think maps will also enhance student memory.

The continuous use of I-Think thinking maps in pdpc can enhance students' memory skills. This is because the delivery of learning content by the teacher can be delivered more effectively and not boring the students. Students are also encouraged to use the I-Think map in taking notes to enhance students' level of understanding and memory of their lessons. According to Buzan (2003), the use of mind maps can be applied in many forms and can be applied in learning. Through the use of mind maps, we can improve student achievement in learning. According to Khan (2006), the use of mind map as a tool of thinking among students can create a global, interactive, democratic environment and the ability to encourage students to think in improving their achievement.

I-THINK mind map is one of the tools of thought. In addition, students can use other mind maps such as Habits of Minds, Thinking Hats, Thinkers Keys, clustering, Three Story intellect, scampers, Route Technique, DATT, Mind Mapping and Brainstorming and the Thinking Sandwich. Thinking skills become a practice when teachers and students use in the classroom through activities that require high-level inquiry, inquiry, and student-centered thinking. Teachers act as facilitators to encourage students to ask questions during classroom activities. Students are responsible for their learning.

\section{Conclusion}

The use of I-THINK maps greatly influences students to study History subjects and can increase student motivation. Creativity of teachers plays an important role so that students can learn to learn history. The mastery of students in the eight petals of I-THINK will help students to remember facts easily. The role of teachers is also very important in explaining each of the eight functions of the I-THINK thinking map. Students are more productive in teaching and learning history. This is because, using I-THINK Maps and concept maps, students can easily understand a given fact. Indirectly it will also attract students. Therefore, the use of ITHINK maps is one of the most effective teaching techniques in increasing student interest and achievement in history subjects. Teachers play a very important role in making history a subject that students in the school enjoy. Teachers need to be more prepared to use creativity and innovation to make the teaching process in the classroom more enjoyable and fun.

\section{References}

[1] Abdosamad, M.I.I. 2007. Pembangunan dan penilaian modul pembelajaran berkonsepkan peta minda bagi subjek pengajian Kejuruteraan Elektrik. Tesis Sarjana. Universiti Tun Hussien Onn Malaysia.

[2] Hyerle, D. \& Yeager, C.2007. A Language for learning: Thinking maps incorporated. North Carolina; Thinking Maps. Inc.

[3] Haslina Mohd Ismail. 2012. Kesan penggunaan peta minda dalam pembelajaran dalam mata pelajaran sejarah. Tesis. Fakulti Pendidikan Teknik dan Vokasional. Universiti Tun Hussein Onn Malaysia.

[4] Kementerian Pelajaran Malaysia. 2012. Bahagian Pembangunan Kurikulum. Membudayakan kemahiran berfikir. Buku. Retrieved from http://www.moe.gov.my/bpk

[5] Mohd Mahzan Awang (et. al.) (2014). Penggunaan peta minda oleh pelajar pintar cerdas dalam pembelajaran Sejarah. Jurnal Pendidikan Malaysia, Vol. 39(2), hlm. 95-100. Bangi : Universiti Kebangsaan Malaysia.

[6] Muhammad Faiz Tamdjis \& Anuar Ahmad. Penggunaan peta pemikiran I-THINK terhadap pencapaian dan minat pelajar dalam pendidikan sejarah. Kertas kajian.

[7] Muhamad Sidek Said \& Ahamad Rahim. (2012a). Inovasi pengajaran dan pembelajaran melalui program i-THINK. Kertas kerja dibentangkan di IPGM International Convention in Teacher Learning \& Development, Pearl International Hotel, Kuala Lumpur, 19-21 Nov 2012.

[8] Shamsazila Sa'aban, Muhammad Faizal \& Ghazali Darusalam. 2017. Pendedahan program I-Think di peringkat sekolah mengikut pendekatan sekolah secara menyeluruh. Satu kajian awal. Jurnal Kepimpinan Pendidikan. Bil 4.

[9] Subadrah Nair. (2005). Penggunaan model konstruktivisme lima fasa NEEDHAM dalam pembelajaran Sejarah. Jurnal Pendidik dan Pendidikan, Jil. 20, hlm. 21-41. Pulau Pinang : Universiti Sains Malaysia.

[10] Taha, M. 2004. Belajar cara mudah. Peningkatan minda. Pusat Pengajian Umum, Bangi UKM.

[11] Wineburg, S. (2001). Making Historical Sense. In Stearns, P.N. Seixas, P. and Wineburg, S.(eds.). Knowing Teaching and Leraning History : National and 
International Perspectivespp. 307-325. New York : New York University Press.

[12] Yahya Othman (et. al.) (2012). Keberkesanan Penggunaan Peta Minda Dalam Pengajaran Dan Pembelajaran Karangan Argumentatif Di Sebuah Sekolah Menengah Arab Di Negara Brunei Darussalam. Jurnal Pendidikan Bahasa Melayu, Vol. 2 Bil. 2. hlm. 32-45. Bangi : Universiti Kebangsaan Malaysia

[13] Zaharah Aziz (et. al.) (2009). Penggunaan peta konsep untuk meningkatkan pencapaian matapelajaran Sejarah bagi pelajar Tingkatan 2. Jurnal Pendidikan Malaysia, Vol. 34(1), hlm. 3-15. Bangi : Universiti Kebangsaan Malaysia. 